\title{
The effect of abomasal infusion of casein on acetate, palmitate and glucose kinetics in cows during early lactation
}

\author{
BY BAR BARA A. KÖNIG, ${ }^{1}$ J. D. OLDHAM ${ }^{2}$ AND D. S. PARKER ${ }^{1} \uparrow$ \\ 1 Department of Physiology and Biochemistry, University of Reading, Whiteknights, \\ Reading RG6 $2 A J$ \\ 2 National Institute for Research in Dairying, Shinfield, Reading RG2 9AT
}

\section{(Received 16 February 1984 - Accepted 26 March 1984)}

\begin{abstract}
1. Four mature Friesian cows were used in a Latin square design experiment to measure the effects of abomasal casein infusion on milk production and the kinetics of glucose, acetate and palmitate in jugular venous blood.

2. The basal ration contained $110 \mathrm{~g}$ crude protein $/ \mathrm{kg}$ dry matter and was offered at the rate of $4 \mathrm{~kg}$ hay, $3 \mathrm{~kg}$ alkali-treated straw cubes plus $9 \mathrm{~kg}$ concentrates/d. Treatments were infusion of casein into the abomasum at the rate of 0,240 or $460 \mathrm{~g} / \mathrm{d}$. The experiment started 1 week post partum. Experimental periods lasted $21 \mathrm{~d}$.

3. $\left[6-{ }^{3} \mathrm{H}\right]$ glucose, $\left[9,10^{-3} \mathrm{H}\right]$ palmitate and $\left[\mathrm{U}-{ }^{14} \mathrm{C}\right]$ acetate were continuously infused into one jugular vein for measurements of whole-body flux rates.

4. The yield of milk protein was increased significantly $(P<0.05)$ by the first increment of casein infusion, with no further increases.

5. Casein infusion had no effect on blood concentrations of glucose, acetate, palmitate or growth hormone. Mean flux rate of glucose increased with each increment of casein. The effect at $460 \mathrm{~g} / \mathrm{d}$ was higher $(P<0 \cdot 1)$ than with no infusion. Flux rates of palmitate and acetate were increased $(P<0 \cdot 1)$ by the first increment of casein. The proportion of blood bicarbonate derived from acetate increased $(P<0.05)$ with the first increment of casein.

6. Protein status of cows early in lactation influences the dynamics of glucose and fatty acid metabolism.
\end{abstract}

Results from a number of experiments have shown that yields of milk protein in both cows and goats can be increased by infusion of casein into the abomasum (Clark, 1975; Ørskov et al. 1977; Ranawana \& Kellaway, 1977). The specific component in casein that produces this response has not been indentified, although Clark (1975) has suggested that the infused protein may increase milk yield directly, by supplying limiting amino acids, or indirectly, either by supplying carbon for gluconeogenesis or by altering hormone balance. A further hypothesis, that an additional amino acid supply at the duodenum increases milk production by increasing the mobilization of energy in support of lactation, was proposed by Ørskov et al. (1977). These workers found that, as well as increasing milk yield and milk protein yield, infusion of casein into cows which had been deliberately underfed in early lactation resulted in a doubling of the calculated negative energy balance and a twofold increase in blood non-esterified fatty acid (NEFA) concentration.

Further indirect evidence of an effect of improved protein supply to the tissues on energy partition in cows which were in negative energy balance in early lactation has been given by Ørskov et al. (1981). In this instance cows were offered supplemented protein either as fish meal or as groundnut meal. For cows which were already in negative energy balance the fish meal supplement, which might be expected to have increased total amino acid supply to the tissues (Agricultural Research Council, 1980), increased calculated energy deficits in comparison with the groundnut supplement.

The work reported here was designed to investigate, directly, any effects on the metabolism of energy-yielding nutrients of increasing protein supply to the tissues of dairy

$\dagger$ Present address: Department of Agricultural Biochemistry and Nutrition, University of Newcastle, Newcastle upon Tyne NEl 7RU. 
cows in early lactation. As indices of fatty acid metabolism, we used whole-body fluxes of acetate and palmitate (König et al. 1979). To examine any effects of protein supplementation on metabolism of glucose, whole-body flux of glucose was also measured. It has sometimes been observed that modification of protein status in lactating ruminants can influence concentrations of growth hormone (GH) in blood (Oldham et al. 1978, 1982). For this reason blood GH concentrations are also reported. A preliminary report of this work has been published (König et al. 1981).

EXPERIMENTAL

\section{Animals and management}

Four mature Friesian cows were used. They were prepared surgically in the fourth or fifth month of pregnancy with an abomasal fistula. A Folatex catheter with a 75-100 ml balloon (Escham Bros. and Walsh Ltd, Lancing, Sussex) was inserted into the fistula a few weeks after surgery and was replaced as necessary.

The cows were housed in concrete stalls and milked twice daily at 08.00 and 16.00 hours. They were offered daily $4 \mathrm{~kg}$ hay, $3 \mathrm{~kg}$ alkali-treated straw cubes and $9 \mathrm{~kg}$ pelleted concentrates $(\mathrm{g} / \mathrm{kg}$ : barley 700 , maize 237 , urea 13 , mineral supplement 50$)$. The whole ration contained $110 \mathrm{~g}$ crude protein $(\mathrm{N} \times 6 \cdot 25) / \mathrm{kg}$ dry matter.

In order to establish, as closely as practicable, a steady state for the tracer kinetic measurements, the concentrates were dispensed in equal portions at hourly intervals and hay was given in four portions at equal time intervals between 06.00 and 22.00 hours. There were no refusals of food during the experimental period.

\section{Treatments and design}

The cows were supplemented per abomasum with 0,240 and $460 \mathrm{~g} / \mathrm{d}$ sodium caseinate in a $3 \times 3$ Latin square experimental design modified for an extra cow as described by Pearce (1952). Treatment periods lasted $21 \mathrm{~d}$ beginning 1 week post partum; measurements were made during the last week of each period.

\section{Procedure}

Sodium chloride $(0 \cdot 16 \mathrm{M})$ and sodium caseinate $(50$ or $100 \mathrm{~g} / 1$ in water) were infused into the abomasum at a known rate.

The day before each experiment the cows were fitted with indwelling catheters (Portex Ltd, Hythe, Kent) in each jugular vein, to allow continuous infusion of metabolite tracers. On one occasion (period $3,240 \mathrm{~g}$ casein infused/d), when only one vein could be catheterized, a single injection of tracer was used.

To measure whole-body flux rates of acetate, palmitate and glucose, [U-14 $\mathrm{C}]$ acetate, $\left[9,10-{ }^{3} \mathrm{H}\right]$ palmitate and $\left[6-{ }^{3} \mathrm{H}\right]$ glucose were infused simultaneously into the jugular infusion catheter for $1 \cdot 5,2$ and $4 \mathrm{~h}$ respectively.

$\left[6-{ }^{3} \mathrm{H}\right] \mathrm{glucose}$ was chosen in preference to $\left[\mathrm{U}-{ }^{14} \mathrm{C}\right] \mathrm{glucose}$ so that flux rate measurements for glucose included the extent of cycling of carbon between glucose and lactate (Cori cycling) since it is known that Cori cycling may account for up to $15 \%$ of glucose flux in lactating ruminants (Kronfeld, 1977; Wilson et al. 1981). The choice of $\left[6-{ }^{3} \mathrm{H}\right]$ glucose rather than $\left[\mathrm{U}_{-14}{ }^{14} \mathrm{C}\right] \mathrm{glucose}$ also reduced experimental costs.

Sodium $\left[\mathrm{U}-{ }^{14} \mathrm{C}\right]$ acetate $(2 \mathrm{mCi})$ and $\left[6-{ }^{3} \mathrm{H}\right]$ glucose $(2 \mathrm{mCi})$ (Amersham International, Amersham, Bucks) were dissolved in sterile saline $(0 \cdot 16 \mathrm{M}) .\left[9,10{ }^{3} \mathrm{H}\right]$ palmitic acid $(5 \mathrm{mCi}$; Amersham International) in n-hexane-benzene $(1: 1 \mathrm{v} / \mathrm{v})$ was dried under nitrogen at $40^{\circ}$ and taken up in $0.5 \mathrm{ml}$ potassium hydroxide $(0.2 \mathrm{M})$. Approximately $15 \mathrm{ml}$ plasma was added and the mixture diluted with sterile saline $(0 \cdot 16 \mathrm{M})$. The infusion rate for each isotope (approximately $1 \mathrm{ml} / \mathrm{min}$ ) was measured by weight. Samples of blood were removed from 
the opposite catheter immediately before infusion and during the final $30-90 \mathrm{~min}$ of each infusion period.

In the single injection experiment the radioisotopes in approximately $20 \mathrm{ml}$ sterile saline $(0.16 \mathrm{M})$ were injected into one jugular catheter, followed by an equal volume of unlabelled saline solution. This procedure took about $30 \mathrm{~s}$. Samples of blood were then withdrawn with decreasing frequency, for up to $2.5 \mathrm{~h}$ after injection. The volume of infusate injected was measured by weight.

Samples of milk were taken from the last six consecutive milkings in each experimental period; milk composition was measured in a sample bulked in proportion to yield.

\section{Analyses}

The concentrations of fat, protein and lactose in milk were measured on an infra-red milk analyser (IRMA, Mark II; Grubb Parsons, Newcastle upon Tyne).

Blood samples $(15 \mathrm{ml})$ for analysis of glucose were immediately deproteinized by mixing with deionized water $(30 \mathrm{ml})$ and with the addition of $0.15 \mathrm{M}$-barium hydroxide $(15 \mathrm{ml})$ and $0.3 \mathrm{M}$-zinc sulphate $(15 \mathrm{ml})$ according to Somogyi (1945). They were centrifuged at $3000 \mathrm{~g}$ for $15 \mathrm{~min}$. The concentration of glucose in the supernatant fraction was measured using an automated procedure (Boehringer Co., Lewes, East Sussex) based on the glucose oxidase method of Werner et al. (1970). Glucose was prepared for radioactive counting by isolating the $\beta$-glucose pentaacetate (GPA) derivative as described by Jones (1965).

In continuous infusion experiments the specific radioactivity (SRA) of blood carbon dioxide was estimated by the method of Hinks et al. (1966). Plasma volatile fatty acids (VFA) were extracted from $1 \mathrm{ml}$ plasma by the method of Gardner \& Thompson (1974). The concentration of plasma acetate was determined by gas-liquid chromatography (Pye 104, Pye Unicam Ltd, Cambridge), ${ }^{14} \mathrm{CO}_{2}$ in the effluent from the flame ionization detector corresponding to acetate in the sample was trapped using a descending film absorption cell system based on that of Wels (1977). The overall efficiency of the system (approximately $45 \%$ ) was measured by collecting ${ }^{14} \mathrm{CO}_{2}$ from a $\left[\mathrm{U}^{-14} \mathrm{C}\right]$ acetate standard. The efficiency of extraction of acetate from plasma was approximately $100 \%$.

Plasma lipids were extracted from $1 \mathrm{ml}$ plasma by the method of Folch $e t$ al. (1957) as modified by Storry \& Millard (1965). The extracted lipids were separated by thin-layer chromatography as described by Tuckley \& Storry (1974). Fatty acid methyl esters were prepared and the concentration of palmitate was determined by gas-liquid chromatography (Pye 104). Radioactivity in $10 \mu \mathrm{l}$ of the methylated sample was corrected for the efficiency of extraction of NEFA in each sample (approximately $70 \%$ ).

Radioactivity in infusates and samples was measured on a Packard Tricarb Model 3255 liquid scintillation counter. Plasma GH was measured by radio-immunoassay (Hart et al. 1975 ) with the modification that bovine GH (NIH-GH-B, $1.5 \mathrm{i} . \mathrm{u} . / \mathrm{mg})$ was used as both the iodinated hormone and standard.

\section{Calculations}

In continuous infusion experiments metabolite flux rate was calculated by dividing the infusion rate by the 'plateau' SRA of the metabolite. In the single injection experiment metabolite flux rates were estimated as described by Shipley \& Clark (1972):

$$
\text { flux rate }=\frac{I}{\int_{0}^{\infty} \operatorname{SRA} d t},
$$

where $I$ is the specific radioactivity (disintegrations/min) injected and SRA is the specific radioactivity of the metabolite at time $t$ after injection. 

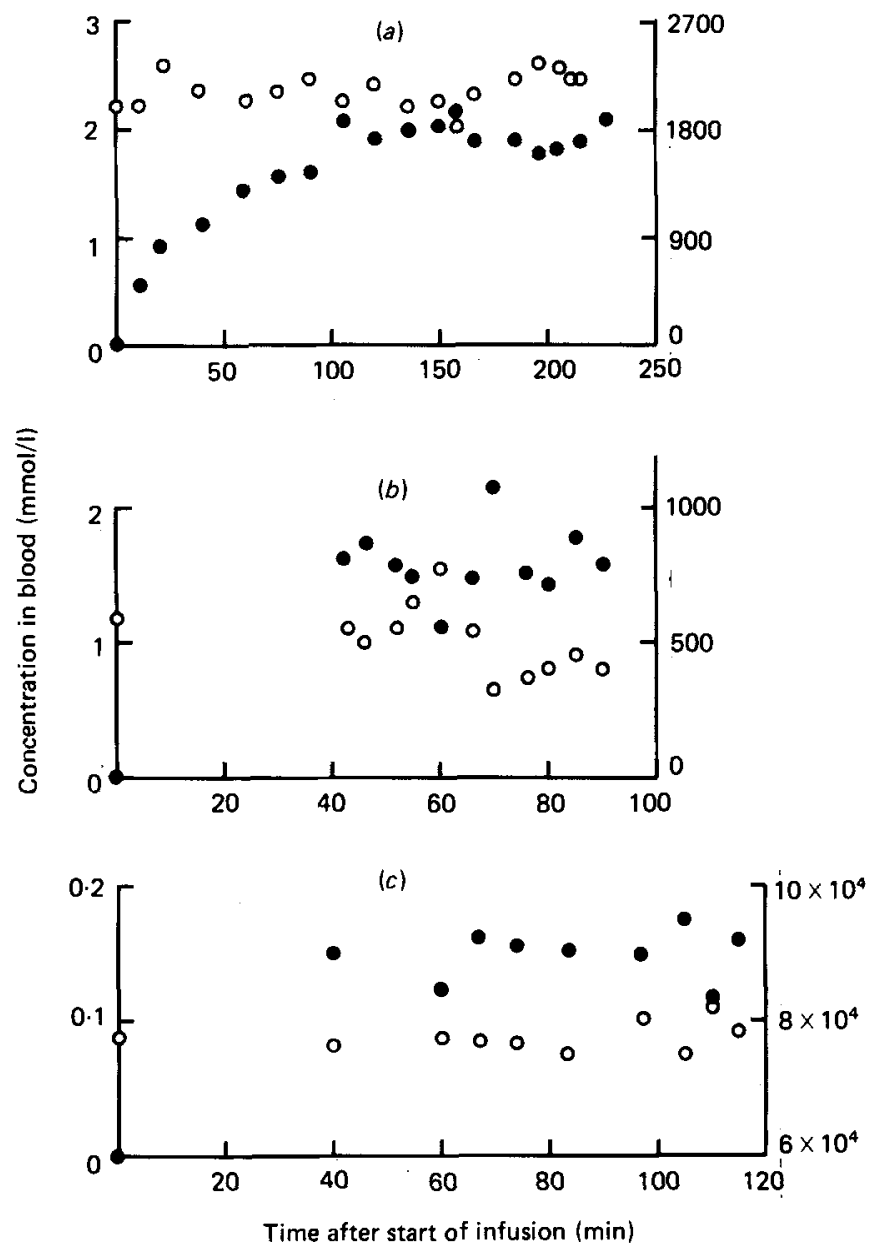

Fig. 1. An example of the changes in the concentration $(O)$ and specific radioactivity $(O)$ of $(a)$ glucose, (b) acetate and (c) palmitate in jugular venous blood of a cow during intravenous infusion of $\left[6-{ }^{3} \mathrm{H}\right] \mathrm{glucose}$, [U-14 $\mathrm{C}]$ acetate and $\left[9,10-{ }^{3} \mathrm{H}\right]$ palmitate.

The $\log _{\mathrm{e}}$ SRA $v$. time curves were not linear and were interpreted as the sum of two exponential functions:

$$
\mathrm{SRA}=A \mathrm{e}^{-\alpha t}+B \mathrm{e}^{-\beta t},
$$

by using a least squares procedure to fit the curves.

Statistical analysis. The results were analysed according to Pearce (1952).

\section{RESULTS}

Validity of measurements of flux rate

It is important in experiments of this kind that the assumptions of the method are met; in particular, with estimates of metabolite flux, the pools of the metabolite under study should be in a dynamic steady state (Shipley \& Clark, 1972). Fig. 1 gives examples of the pattern of SRA and plasma concentrations of glucose, acetate and palmitate obtained in flux measurements. 
Table 1. Effect of abomasal infusion of casein on milk yield $(l / d)$, the composition of milk $(\mathrm{g} / \mathrm{l})$ and production of milk constituents $(\mathrm{g} / \mathrm{d})$ of cows

\begin{tabular}{|c|c|c|c|c|c|c|c|}
\hline \multirow{2}{*}{$\begin{array}{l}\text { Treatment } \\
\text { (g sodium } \\
\text { caseinate } / \mathrm{d})\end{array}$} & \multirow{2}{*}{$\begin{array}{l}\text { Milk yield } \\
\text { (l/d) }\end{array}$} & \multicolumn{3}{|c|}{ Milk composition $(\mathrm{g} / \mathrm{l})$} & \multicolumn{3}{|c|}{ Yield of milk constituents $(\mathrm{g} / \mathrm{d})$} \\
\hline & & Protein & Fat & Lactose & Protein & Fat & Lactose \\
\hline 0 & $22 \cdot 1$ & 27.6 & 40.8 & $44 \cdot 8$ & $607^{a}$ & 906 & 992 \\
\hline 240 & 23.8 & $29 \cdot 4$ & $38 \cdot 1$ & $45 \cdot 7$ & $697^{b}$ & 909 & 1085 \\
\hline 460 & $23 \cdot 5$ & $29 \cdot 1$ & $41 \cdot 0$ & $45 \cdot 2$ & $683^{\mathrm{b}}$ & 960 & 1065 \\
\hline $\begin{array}{l}\text { Standard error of } \\
\text { difference between } \\
\text { means }(4 \mathrm{df})\end{array}$ & 0.92 & $1 \cdot 05$ & $1 \cdot 49$ & 0.89 & $24 \cdot 9$ & $51 \cdot 0$ & $50 \cdot 2$ \\
\hline
\end{tabular}

$\mathrm{a}, \mathrm{b}$ Values in the same column which do not share a common superscript letter were significantly different $(P<0.05)$.

Table 2. Effect of abomasal infusion of casein on glucose concentration ( $\mathrm{mmol} / \mathrm{l})$ and glucose flux rate $(\mathrm{mg} / \mathrm{min})$ in jugular blood of lactating cows

\begin{tabular}{ccc}
\hline \hline $\begin{array}{c}\text { Treatment } \\
\text { (g sodium } \\
\text { caseinate/d) }\end{array}$ & $\begin{array}{c}\text { Goncentration } \\
(\mathrm{mmol} / \mathrm{l})\end{array}$ & $\begin{array}{c}\text { Flux } \\
(\mathrm{mg} / \mathrm{min})\end{array}$ \\
\hline 0 & $2 \cdot 14$ & $1341^{\mathrm{a}}$ \\
240 & $2 \cdot 11$ & $1506^{\mathrm{ab}}$ \\
460 & $2 \cdot 24$ & $1528^{\mathrm{b}}$ \\
& $0 \cdot 129$ & $113 \cdot 1$ \\
& & \\
Standard error of \\
difference between \\
means (4 df)
\end{tabular}

a,b Values in the same column which do not share a common superscript letter were significantly different $(P<0 \cdot 1)$.

The steady pattern of SRA and concentration were taken as reasonable validation that the cows were in a metabolic steady state when the measurements were made.

\section{Milk yield and composition}

Infusion of casein produced small, non-significant increases in both milk yield and concentration of protein in milk (Table 1$)$. Milk protein was significantly $(P<0.05)$ increased by casein infusion. There was no change in either concentration or yield of lactose or fat in milk.

\section{Glucose metabolism}

Blood glucose concentration was not affected by treatment but glucose flux rate was increased significantly $(P<0 \cdot 1)$ by infusion of $460 \mathrm{~g}$ sodium caseinate/d (Table 2).

\section{Acetate metabolism}

Plasma acetate concentration was not affected by treatment, but acetate flux rate was significantly $(P<0.1)$ increased by infusion of $240 \mathrm{~g}$ sodium caseinate/d (see Table 3$)$. The proportion of blood $\mathrm{CO}_{2}$ derived from acetate was also increased significantly $(P<0.05)$ by infusion of 240 and $460 \mathrm{~g}$ casein/d (Table 3 ). 
Table 3. Effect of abomasal infusions of casein on the concentration (mmol/l) and flux rate ( mmol/min) of acetate and on the contribution of acetate to carbon dioxide production in jugular blood of lactating cows

\begin{tabular}{|c|c|c|c|}
\hline \multirow{2}{*}{$\begin{array}{l}\text { Treatment } \\
\text { (g sodium } \\
\text { caseinate } / \mathrm{d})\end{array}$} & \multicolumn{2}{|c|}{ Acetate } & \multirow{2}{*}{$\begin{array}{l}\text { Proportion of } \\
\mathrm{CO}_{2} \text { derived } \\
\text { from acetate }\end{array}$} \\
\hline & $\begin{array}{l}\text { Concentration } \\
(\mathrm{mmol} / \mathrm{l})\end{array}$ & $\underset{(\mathrm{mmol} / \mathrm{min})}{\text { Flux }}$ & \\
\hline 0 & 1.52 & $29^{\mathrm{a}}$ & $0 \cdot 10^{\mathrm{c}}$ \\
\hline 240 & $2 \cdot 13$ & $94^{b}$ & $0 \cdot 35^{\mathrm{d}^{*}}$ \\
\hline 460 & 1.44 & $84^{\mathrm{ab}}$ & $0 \cdot 27^{\mathrm{d}}$ \\
\hline $\begin{array}{l}\text { Standard error of } \\
\text { difference between } \\
\text { means ( } 4 \mathrm{df} \text { ) }\end{array}$ & 0.394 & $26 \cdot 7$ & $0.0551,0.0595^{*}$ \\
\hline
\end{tabular}

$a, b, c, d$ Values in the same column which do not share a common superscript letter were significantly different: a, b $P<0.1,{ }^{\text {c, d }} P<0.05$.

$* 3 \mathrm{df}$.

Table 4. Effect of abomasal infusion of casein on the plasma concentrations (mmol/l) of palmitate, stearate and oleate and the flux rate of palmitate $(\mu \mathrm{mol} / \mathrm{min})$ in jugular blood in lactating cows

\begin{tabular}{|c|c|c|c|c|}
\hline \multirow{2}{*}{$\begin{array}{l}\text { Treatment } \\
\text { (g sodium } \\
\text { caseinate } / \mathrm{d})\end{array}$} & \multicolumn{3}{|c|}{ Concentration $(\mathrm{mmol} / \mathrm{l})$} & \multirow{2}{*}{$\begin{array}{l}\text { Palmitate flux } \\
(\mu \mathrm{mol} / \mathrm{min})\end{array}$} \\
\hline & Palmitate & Stearate & Oleate & \\
\hline 0 & $0 \cdot 14$ & $0 \cdot 11$ & 0.08 & $715^{\mathrm{a}}$ \\
\hline 240 & 0.09 & $0 \cdot 10$ & 0.09 & $1032^{\mathrm{b}}$ \\
\hline 460 & $0 \cdot 11$ & 0.09 & 0.06 & $892^{\mathrm{ab}}$ \\
\hline $\begin{array}{l}\text { Standard error of } \\
\text { difference between } \\
\text { means }(4 \mathrm{df})\end{array}$ & 0.03 & 0.03 & 0.04 & 176 \\
\hline
\end{tabular}

$a, b$ Values in the same column which do not share a common superscript letter were significantly different $(P<0 \cdot 1)$.

\section{Palmitate metabolism}

Plasma palmitate concentration was not affected by treatment, but palmitate flux rate increased significantly $(P<0 \cdot 1)$ as a result of infusing $240 \mathrm{~g}$ casein/d (Table 4).

\section{Plasma GH}

Mean (with SED) concentrations of GH in plasma were $7 \cdot 7,4 \cdot 7$ and $5.9(1 \cdot 77) \mathrm{ng} / \mathrm{ml}$ at 0 , 240 and $460 \mathrm{~g}$ casein/d respectively. The differences were not significant.

\section{DISCUSSION}

Abomasal infusion of $240 \mathrm{~g}$ casein/d increased milk yield by $8 \%$ and yield of milk protein by $15 \%$ but no further response was achieved by increasing casein supplementation to $460 \mathrm{~g} / \mathrm{d}$. This scale of response and pattern of diminishing return to increments of casein is comparable to results of other studies with well-nourished cows (Clark, 1975; Vik-Mo et al. 1974; Clark et al. 1977). Similar increases in milk protein yield have also been recorded 
in feeding experiments when cows have been given dietary protein supplements (Oldham et al. 1979; Claypool et al. 1980; Phipps et al. 1981). However, much bigger responses to abomasal supplements of casein were reported by Ørskov et al. (1977) who deliberately underfed their cows to enforce a substantial negative energy balance and the effect of casein supplementation was to enhance energy deficit. In contrast, by calculation, using standard values for the metabolizable energy (ME) content of feed ingredients (Ministry of Agriculture, Fisheries and Food, 1977) and the assumptions described by Ørskov et al. (1981), the cows used in our study were in negative energy balance throughout $(-23,-21$ and $-23 \mathrm{MJ} \mathrm{ME} / \mathrm{d}$ for treatments 0,240 and $480 \mathrm{~g}$ casein/d respectively) but the extent of energy deficit was not affected by casein supplementation.

An important difference between the cows used by Ørskov et al. (1977) and those used in the present study was the extent of underfeeding (negative energy balance) imposed by the basal ration. Ørskov et al. (1981) observed that cows in slight negative energy balance did not respond to replacement of a highly degradable dietary protein source (groundnut meal) by a relatively undegradable dietary protein source (fish meal), but cows in substantial energy deficit did. It has been suggested that part of the reason for this sort of difference may be in the nature of the energy-yielding nutrients provided by the diet rather than, simply, the level of feeding (Lees et al. 1982). Rumen fermentation of diets which contain a high proportion of starch may result in an enhanced secretion of insulin favouring partition of nutrients towards body tissue rather than milk (Hart, 1983). The potential for a large production response to supplemental protein may therefore be reduced and this may have been a factor contributing to the lower response to casein in the present experiment where a diet with a high cereal content was used.

\section{Tracer measurements}

Casein infusion increased mean flux rates of glucose, acetate and palmitate at the level of significance $P<0 \cdot 1$. The nature of the measurements, and their cost, inevitably results in experiments of this kind being small in scale with consequent difficulties in achieving conventional levels $(P<0.05)$ of significance in observed effects.

Special care is therefore needed in interpretation of the observations. Our results for glucose flux substantiate those of others (Clark et al. 1977; Ranawana \& Kellaway, 1977) who also found that casein infusion had non-significant $(P>0.05)$ effects on glucose flux. This consistency between experiments strongly suggests the effect is real. At present there are no other results against which to compare our results for acetate and palmitate.

\section{Glucose metabolism}

The increase in glucose flux when casein was infused, measured as change in glucose flux ( $\mathrm{g} / \mathrm{d}$ per g supplemental casein), was similar in magnitude to earlier reports (Table 5) and substantial in comparison with theoretical assessments of potential glucose yield from glucogenic amino acids, usually quoted as $550 \mathrm{~g}$ glucose $/ \mathrm{kg}$ protein (Krebs, 1965). However, it seems unlikely that the change in flux was wholly the result of increased gluconeogenesis from amino acids. As Lindsay (1976) has pointed out, direct oxidation of amino acids substantially exceeds glucogenesis, typically in the ratio $4: 1$. If we assume this ratio of amino acid oxidation to gluconeogenesis from amino acids for the increments of casein applied here and also allow for increased secretion of protein in milk, then $7-16 \%$ of the increase in glucose flux would have been attributable to gluconeogenesis from acids.

Some of the increase in glucose supply may have come via glycerol release from triglyceride if the increase in palmitate flux was the result of enhanced lipolysis. With palmitate constituting 25 molar \% of adipose tissue triglyceride (Christie, 1981) this source could have accounted for $12-23 \%$ of the increased glucose flux. 
Table 5. Effect of abomasal infusion of casein on glucose fux rate

\begin{tabular}{|c|c|c|c|c|c|c|}
\hline \multirow[b]{2}{*}{ Animals } & \multirow[b]{2}{*}{$n$} & \multirow{2}{*}{$\begin{array}{l}\text { Quantity } \\
\text { of casein } \\
\text { infused } \\
(\mathrm{g} / \mathrm{d})\end{array}$} & \multicolumn{2}{|c|}{$\begin{array}{l}\text { Glucose flux } \\
\text { rate }(g / d)\end{array}$} & \multirow{2}{*}{$\begin{array}{c}\text { Glucose } \\
\text { produced } / \mathrm{kg} \\
\text { casein } \\
\text { infused }\end{array}$} & \multirow[b]{2}{*}{ Reference } \\
\hline & & & Control & + Casein & & \\
\hline Sheep & 5 & 100 & 64 & 99 & 350 & Lindsay \& Williams, 1971 \\
\hline Lactating goats & 3 & 45 & 164 & 201 & 820 & Ranawana \& Kellaway, 1977 \\
\hline Lactating cows & 4 & 422 & 2760 & 2890 & 300 & Clark et al. 1977 \\
\hline \multirow[t]{2}{*}{ Lactating cows } & 4 & 240 & 1931 & 2169 & $990\}$ & Present study \\
\hline & & 460 & 1931 & 2200 & $570\}$ & Present study \\
\hline
\end{tabular}

As we chose to use $\left[6-{ }^{3} \mathrm{H}\right]$ glucose to monitor glucose metabolism it is possible that increased Cori cycling accounted for part of the observed changes in glucose flux (Dunn et al. 1976), although both Clark et al. (1977) and Ranawana \& Kellaway (1977) used $\left[\mathrm{U}-{ }^{14} \mathrm{C}\right]$ glucose and found similar changes to those found here (Table 5), which would imply that enhanced Cori cycling was not great. Views differ on the extent of Cori cycling in lactating ruminants. In sheep as little as $2 \%$ (Baird et al. 1983) up to $15 \%$ (Wilson et al. 1981) of glucose flux has been attributed to Cori cycling. In dairy cows the range is $2-6 \%$ (Kronfeld, 1977; Baird et al. 1983). If we assume that the extent of Cori cycling on the basal (saline) treatment was minimal at $2 \%$ then, to account for the increase in glucose flux above that from gluconeogenesis (from amino acids) and glycerol release, described above, Cori cycling would have to have risen to $9-11 \%$ of glucose flux.

The fate of enhanced glucose production is equally unclear. Only $29-41 \%$ of the increase in glucose flux appeared as extra lactose secreted in milk. The remainder would either have been oxidized or transferred into other metabolic compartments. It seems unlikely that glucose oxidation would have increased when casein was infused. Clark et al. (1977) noted a fall in glucose oxidation under these circumstances. Enhanced Cori cycling of the extent noted above would, in fact, suggest that glucose oxidation was reduced slightly. A considerable amount of glucose carbon may have entered compartments with a slow turnover, for example protein-bound amino acids (Wilson et al. 1983) and hence have been apparently irreversibly lost from blood during our measurements.

\section{Acetate and palmitate metabolism}

The results presented here are the first to show, directly, an effect of supplemental protein on the dynamics of fatty acid metabolism in cows.

That both palmitate and acetate flux rates were found to increase on supplementation with casein suggests that the effect was real, albeit at a modest level of statistical significance $(P<0 \cdot 1)$. It may also suggest that some NEFA contributed to enhanced acetate flux which would agree with the suggestion of Pethick et al. (1983) that some NEFA may be oxidized indirectly via ketone bodies and acetate. However, the contribution of NEFA to acetate flux, even assuming that the flux of all NEFA was increased in proportion to palmitate and that all of the increase was converted to acetate, would account for less than one-fifth of the increase in acetate flux.

It is difficult to account for the size of the change in acetate flux. The major contributor to blood acetate is usually absorption from the gastrointestinal tract (Pethick et al. 1981). Rumen acetate production for the diet used here would have been close to $40 \mathrm{~mol}$ (4-4.5 M acetate $/ \mathrm{kg}$ digestible dry matter consumed; Sutton, 1984) which is very similar to the blood acetate flux on the basal ration. Unabsorbed casein may have stimulated hind-gut 
fermentation and increased acetate production therein but it is not reasonable to expect a change of the observed magnitude.

Measurements of acetate flux in peripheral blood are likely to be overestimates to the extent that there is some acetate metabolism by the liver (Annison \& Lindsay, 1962). If casein infusion had, for some reason, increased acetate utilization by the liver, an increased artefactual, peripheral acetate flux would have resulted. However, it is not realistic to suggest that a change in liver metabolism would have produced such a large change as that which was observed.

The increase in proportion of blood $\mathrm{CO}_{2}-\mathrm{C}$ derived from acetate both substantiates the suggestion that casein infusion influenced acetate metabolism and shows that a proportion of the increase in acetate flux was disposed of by oxidation. We do not know the $\mathrm{CO}_{2}$ production rate for these cows but with an assumed $\mathrm{CO}_{2}-\mathrm{C}$ production of $3 \mathrm{~kg} / \mathrm{d}$ (J. C. MacRae, personal communication) it would appear that one-quarter to one-third of acetate was oxidized in all cases, suggesting no change in the partition of acetate metabolism between oxidation and other pathways.

The observed effects on palmitate metabolism are consistent with the hypothesis that supplemental protein can enhance mobilization of body fat in cows early in lactation (Orskov et al. 1977, 1981). In our experiment, extra fatty acids made available for milk fat synthesis did not influence the yield of milk fat (Table 1), although there is the possibility that the fatty acid composition of the milk may have changed. This was not determined, however.

Calorimeter experiments have failed to find any shift in partition of energy between body tissue and milk in cows offered different amounts of dietary protein in early lactation (Vermorel et al. 1982). It is unlikely, however, that such measurements would have the precision to detect shifts in heat production of the size which might result from enhanced substrate cycling as indicated by the results of the present work.

A possible link between enhanced protein supply and alterations in fatty acid availability could be GH. Some earlier work has shown effects of altered protein feeding on blood GH concentration (Oldham et al. 1978, 1982; Barry, 1980) and some preparations of the hormone may be lipolytic (Hart, 1983).

No change in circulating concentrations of $\mathrm{GH}$ were observed here but it might be argued that the time period employed to sample blood for $\mathrm{GH}$ was too short to allow treatment effects to be seen for a hormone which is known to be secreted episodically (Hart, 1983). Other work with goats (Gow et al. 1979) and cows (Peel et al. 1982) also failed to produce a change in blood GH concentration when casein was infused into the abomasum. Such differences in response should be viewed against the known complexities of nutrient-endocrine interrelationships, which might give doubt as to the meaning of simple descriptions of nutrient effects, or lack of them, on blood hormone concentrations.

We conclude that the protein status of cows early in lactation can influence the dynamics of glucose and fatty acid metabolism. The systems which control this, and especially the translation of an increased turnover of milk fat and lactose precursors into enhanced secretion in milk, are not yet understood.

B.A.K. acknowledges receipt of a grant from the Science Research Council. We are grateful to Dr H. Buttle for the surgical preparations of the cows, Dr I. C. Hart for analysing plasma GH levels, Mr D. J. Napper for expert technical assistance, and Mrs R. Fulford for help with statistical analysis. 


\section{REFERENCES}

Agricultural Research Council (1980). The Nutrient Requirements of Ruminant Livestock. Farnham Royal: Commonwealth Agricultural Bureaux.

Annison, E. F. \& Lindsay, D. B. (1962). Biochemical Journal 85, 474-479.

Baird, G. D., Van der Walt, J. G. \& Bergman, E. N. (1983). British Journal of Nutrition 80, 249-265.

Barry, T. N. (1980). New Zealand Journal of Agricultural Research 23, 427-431.

Christie, W. W. (1981). In Lipid Metabolism in Ruminant Animals, pp. 95-191 [W. W. Christie, editor]. Oxford: Pergamon Press.

Clark, H. H. (1975) Journal of Dairy Science 58, 1178-1197.

Clark, J. H., Spires, H. R., Derrig, R. G. \& Bennink, M. R. (1977). Journal of Nutrition 107, $631-644$.

Claypool, D. W., Pangborn, M. C. \& Adams, H. P. (1980). Journal of Dairy Sciences 63, 833-837.

Dunn, A., Katz, J., Golden, S. \& Chenoweth, M. (1976) American Journal of Physiology 230, $1159-1162$.

Folch, J., Lees, M. \& Sloane-Stanley, G. H. (1957). Journal of Biological Chemistry 226, 467-509.

Gardner, J. W. \& Thompson, G. E. (1974) Analyst 99, 326-329.

Gow, C. B., Ranawana, S. S. E., Kellaway, R. C. \& McDowell, G. H. (1979). British Journal of Nutrition 41, $371-382$.

Hart, I. C. (1983). Proceedings of the Nutrition Society 42, 181-194.

Hart, I. C., Flux, D. S., Andrews, P. \& McNeilly, A. S. (1975). Hormone and Metabolic Research 7, 35-40.

Hinks, N. T., Mills, S. C. \& Setchell, B. P. (1966). Analytical Biochemistry 17, 551-553.

Jones, G. B. (1965). Analytical Biochemistry 12, 249-258.

König, B. A., Parker, D. S. \& Oldham, J. D. (1979). Annales de Recherches Veterinaires 10, 368-370.

König, B. A., Parker, D. S. \& Oldham, J. D. (1981). Proceedings of the Nutrition Society 40. 18A.

Krebs, H. A. (1965). In Energy Metabolism, pp. 1-9 [K. L. Blaxter, editor]. New York: Academic Press.

Kronfeld, D. S. (1977). Federation Proceedings 36, 259-264.

Lees, J. A., Garnsworthy, P. C. \& Oldham, J. D. (1982). Occasional Publication of the British Society of Animal Production 6, 157-159.

Lindsay, D. B. (1976). In Protein Metabolism and Nutrition, pp. 183-195 [D. J. A. Cole, K. N. Boorman, P. J. Buttery, J. Lewis, R. J. Neale and H. Swan, editors]. EAAP Publication no 16. London: Butterworths.

Lindsay, D. B. \& Williams, R. L. (1971). Proceedings of the Nutrition Society 30, 35A.

Ministry of Agriculture, Fisheries and Food (1977). Energy Allowances and Feeding Systems for Ruminants. Technical Bulletin no. 33. London: H.M. Stationery Office.

Oldham, J. D., Broster, W. H., Napper, D. J. \& Siviter, J. W. (1979). British Journal of Nutrition 42, $149-162$.

Oldham, J. D., Hart, I. C. \& Bines, J. A. (1978). Proceedings of the Nutrition Society 37, 9A.

Oldham, J. D., Hart, I. C. \& Bines, J. A. (1982) British Journal of Nutrition 48, 543-547.

Orskov, E. R., Grugg, D. A. \& Kay, R. N. B. (1977). British Journal of Nutrition 38, 397-405.

Orskov, E. R., Reid, G. W. \& McDonald, I. (1981). British Journal of Nutrition 45, 547-555.

Park, M-S. C. \& Liepa, G. U. (1982). Journal of Nutrition 112, 1892-1898.

Pearce, S. C. (1952). Journal of the Royal Statistical Society. Series B, Methodological 14, $101-106$.

Peel, C. J., Fronk, T. J., Bauman, D. E. \& Gorewit, R. C. (1982). Journal of Nutrition 112, 1770-1778.

Pethick, D. W. Lindsay, D. B., Barker, P. J. \& Northrop, A. J. (1981). British Journal of Nutrition 46, 97-110.

Pethick, D. W., Lindsay, D. B., Barker, P. J. \& Northrop, A. J. (1983). British Journal of Nutrition 49, $129-143$.

Phipps, R. H., Weller, R. F. \& Smith, T. (1981). Journal of Agricultural Science, Cambridge 96, $283-290$.

Ranawana, S. S. E. \& Kellaway, R. C. (1977). British Journal of Nutrition 37, 395-402.

Shipley, R. A. \& Clark, R. E. (1972) Tracer Methods for In Vivo Kinetics. New York: Academic Press.

Somogyi, M. (1945). Journal of Biological Chemistry. 160, 69-73.

Storry, J. E. \& Millard, D. (1965). Journal of the Science of Food and Agriculture 16, 417-420.

Sugano, M., Ishiwaki, N., Nagata, Y. \& Imaizumi, K. (1982). British Journal of Nutrition 48, 21 1-221.

Sutton, J. D. (1984). Journal of Dairy Science (In the Press).

Tuckley, B. \& Storry, J. E. (1974). Lipids 9, 493-494.

Vermorel, M., Redmond, B., Vernet, J. \& Liamadis, D. (1982). In Energy Metabolism of Farm Animals, EAAP

Publication no. 29, p. 18 [A. Edern and S. Sundstol, editors]. Ski, Norway: Informasjonsteknikk A/S.

Vik-Mo, L., Emery, R. S. \& Huber, J. T (1974). Journal of Dairy Science 57, 869-877.

Wels, C. M. (1977) Journal of Chromatography 142, 459-468.

Werner, W., Rey, H. G. \& Wielinger, H. (1970). Fresenius Zeitschriftfuer Analytische Chemie 252, $224-228$.

Wilson, S., MacRae, J. C. \& Buttery, P. J. (1981). Research in Veterinary Science 30, 205-212.

Wilson, S., MacRae, J. C. \& Buttery, P. J. (1983). British Journal of Nutrition 50, 303-316. 